\title{
Revisiting the WTO DDA Negotiations: Analysis of its Current Impasse
}

\author{
YOUNGJEEN CHO*
}

The DDA negotiations were launched in 2001, the first under the auspice of the WTO. The goal of the DDA was to further liberalize trade and to improve existing WTO rules. This paper examines the question what has caused the current impasse of the DDA. In order to address this question, the paper reviews the history of the DDA and analyzes critical issues of the negotiations. The lack of consensus is due to key players failing to minimize the gaps in their positions on critical issues, such as market access of agricultural products. This paper outlines the critical issues of the DDA negotiations and explores the challenges the DDA had to confront.

Keywords: World Trade Organization (WTO), Doha Development Agenda (DDA), Negotiations, Single Undertaking, Uruguay Round (UR), Agriculture, NAMA, Rules, G4, Emerging Economies 


\section{INTRODUCTION}

As of last April, two years have passed since Director-General Pascal Lamy of the World Trade Organization (WTO) acknowledged fundamental and signifycant disparities between members' stances and expressed doubt regarding the successful conclusion of the Doha Development Agenda (DDA) negotiations on his report to the Trade Negotiation Committee (TNC) meeting on April 21, $2011{ }^{1}$ While his remarks were accepted as the demise of DDA by some, ${ }^{2}$ there also existed somewhat optimistic anticipation that the negotiations would resume once political schedules of major participants, such as the US, China, India, Russia, and France, had completed by the end of 2011. Unfortunately, however, the DDA has not been invigorated yet.

The DDA was launched by the Ministerial Declaration adopted at the Fourth Ministerial Conference held in Doha, Qatar ${ }^{3}$ in 2001. It is the ninth multilateral trade negotiations in the history of the General Agreements of Tariffs and Trade (GATT) and WTO, and the first negotiations under the auspice of the WTO. It aims to lower global barriers to trade of agricultural and manufactured products, and of services, and to improve the WTO rules which were last updated with the establishment of the WTO in 1995. In addition, the DDA focuses on the developmental dimensions of trade, as it plays a more important role in global economy and trade than before. And this goal is explicitly reflected on nomenclature, i.e. Doha "Development" Agenda. WTO members expected that the DDA would update the multilateral trading framework represented by the WTO, to meet today's new trading environment as well as that of the next generation, and boost the global economy with further trade liberalization. Members had sought for an "ambitious and balanced"4 outcome across the board for more than 10 years since 2001, but in vain.

Against this backdrop, this paper addresses the question of what has led the DDA to the current impasse. Once we answer this question, it is possible to determine the obstacles that multilateral trade negotiations are facing in the new negotiating environment. In order to answer this question, the paper presents the steps the DDA has taken so far in an attempt to show the challenges it has confronted throughout the negotiations. This paper also compares the negotiating environments and mechanisms of the DDA with those of previous rounds, in particular the Uruguay Round (UR) negotiations held between 1986 and 1994 which lead to the creation of the WTO.

This paper finds that the current impasse of the negotiations is attributable to two factors. First, unlike previous negotiations rounds, far more members are participating in DDA negotiations. In addition, developing countries and emerging economies whose role in global trade has increased significantly over last few decades are no longer shy of participating actively in the negotiations and are 
raising their voices to attain their goals. This means not only an increase in the number of major players at negotiations but also diverse and conflicting interests among them. At the same time, a few developed members, such as the US and EU, are not able to exert their leadership and influence in the negotiations process as they did in previous rounds. However, members adopted a single undertaking rule as a negotiation method, which has not worked well under the new negotiating environment. Second, developed countries and developing countries had far differrent visions and expectations to the outcomes of the DDA negotiations from the beginning. While the former thought the aim of the DDA was trade liberalization, the latter believed developmental dimensions of trade should come first. Consequently, their entrenched positions have not been converged even after a decade of negotiations.

Section 2 outlines the brief history and critical issues of the DDA negotiations. Section 3 explores the challenges the DDA had to confront unlike previous negotiation rounds which led to its current deadlock. Finally, Section 4 provides cautious policy recommendations for the revival or completion of the DDA.

\section{OVERVIEW OF PAST AND PRESENT DDA NEGOTIATIONS}

\section{Brief History of the DDA}

As mentioned, the DDA was launched in November 2001 at the Fourth Ministerial Conference in Doha, with aims to provide further market access to agricultural and manufactured products and services, and to strengthen the WTO rules. The DDA, in addition, focuses on developmental dimensions of trade with an understanding that the goal of the negotiations is not only to increase liberalization but also to address needs and interests of developing countries in all areas of negotiations and to contribute to their economic development. ${ }^{5}$ Initially, these multi-faceted Doha talks were scheduled to be completed by the end of 2004 . However, as key players were unable to resolve their differences, they failed to reach agreements on modalities for negotiations over agricultural and manufactured products by early 2003, as planned. Although the DDA is designed for multilateral trade negotiations where all WTO members may participate equally, in practice major countries have played more active roles and led the negotiations. These key players in the DDA include the US, the EU, Brazil, and India, which are conventionally referred to as the G4, or the new Quad.

Although members were expected to agree on the framework for negotiating modalities at the Fifth Ministerial Conference in Cancún, Mexico in September 2003, they failed to narrow gaps in their stances regarding agricultural and manufactured products. ${ }^{6}$ In addition, developed and developing members clashed over whether so-called "Singapore issues" ${ }^{, 7}$ should be added to the negotiation 
agenda. Developing members criticized the US and EU for imposing an excessive burden on them with these new issues. Also, it was by this time that country groupings, such as the G10, ${ }^{8} \mathrm{G} 20,{ }^{9} \mathrm{G} 33,{ }^{10}$ etc., emerged to join their voices together to represent their common interests.

In July 2004, members finally agreed on the Framework Agreement which established the negotiating parameters. ${ }^{11}$ With the Framework Agreement, momentum for further negotiations was generated, and members gradually engaged in talks to reach agreements on modalities. However, members failed to establish modalities at the Sixth Ministerial Conference in Hong Kong in December 2005, again. Although there was no breakthrough at Hong Kong, members made modest progress as they adopted a work program that provided a clear roadmap for the DDA. $^{12}$ Members set April 30 and July 31, 2006 as due dates for the establishment of modalities and the submission of draft Schedules based on modalities, respectively. ${ }^{13}$ In addition, they agreed to eliminate all forms of export subsidies in agriculture by the end of 2013. ${ }^{14}$

Unfortunately, little progress was made in 2006 to follow up the achievement made at Hong Kong. Four major players, i.e. the US, the EU, Brazil, and India, maintained intransigent positions on three main issues of the DDA, namely agricultural market access, domestic support for agriculture, and market access of manufactured products. After several mini-ministerial meetings in June and July failed to bridge the gaps in key players' positions, Director-General Lamy declared suspension of the negotiations at the TNC meeting on June 24. The negotiations were resumed in early 2007 , and the chairs of the agriculture and the manufactured product negotiating groups circulated draft modalities in July. ${ }^{15}$ Members intensified negotiations around these texts with a hope to conclude the DDA by the end of 2008, and the chairs circulated updated draft modalities in February, May and July reflecting the outcomes of negotiations. When key players managed to minimize the gaps in their positions and agreed on draft modalities on July 25, there was growing anticipation that the agreement on full modalities was imminent. However, despite a credible basis for conclusion on most issues, the deal collapsed because of crucial differences regarding the triggers for a special safeguard mechanism, a device to protect farmers in developing countries against surges of imports. In the aftermath of the failure of the Doha talks, little progress was made in negotiations. As members were unable to reconcile vast differences in their positions, the chairs of negotiating groups were only able to circulate an assessment of the state of negotiations instead of a revised set of negotiating texts on April 21, 2011. It was by then that Director-General Lamy pointed to a clear political chasm that was not bridgeable, and cast serious doubt on the completion of the DDA by the end of the year. Furthermore, the DDA negotiations have not moved forward since then. 


\section{Main Areas and Critical Issues of the DDA}

The negotiation agenda of the DDA negotiations includes, first, providing further market access through the reduction of trade barriers. Further liberalization of trade in agricultural products, ${ }^{16}$ market access for non-agricultural products (NAMA: non-agricultural market access) ${ }^{17}$ and services ${ }^{18}$ came under this category. NAMA conventionally refers to manufactured products negotiations, largely for its convenience. To be exact, however, it is more than market access of manufactured products as it also covers market access of fishery and forestry products. Second, it includes improving disciplines of international trade, which covers rules negotiations, ${ }^{19}$ Agreement on Trade-Related Aspects of Intellectual Property Rights (TRIPS), ${ }^{20}$ the environment, ${ }^{21}$ the Dispute Settlement Understanding (DSU), ${ }^{22}$ and trade facilitation. ${ }^{23}$ Rules negotiations encompass anti-dumping, subsidies, fisheries subsidies, and regional trade agreements (RTA). Trade facilitation deals with customs procedures, such as further expedition of the movement, release and clearance of goods, and the need for enhanced technical assistance and capacity building. ${ }^{24}$ Third, it includes developing countries' problems in implementation of the current WTO Agreements ${ }^{25}$ and special and differential treatment for developing countries. ${ }^{26}$ As the focus of the negotiations has been concentrated on agriculture, NAMA, and rules, this paper also limits its scope of analysis to these three areas.

The negotiations on agriculture are centered on three issues: market access, domestic support and export competition. Market access negotiations aim for substantial improvements in market access, which oversees the tariff reduction formula and exceptions. Once members agree on a formula, it would provide a basis for tariff reduction, under which higher tariffs would be subjected to more substantial adjustments. Members, at the same time, may designate sensitive products as exceptions to tariff reduction, if necessary. While sensitive products can deviate from formula reductions, their tariff-rate quota (TRQ) volume should be expanded. Developing countries are granted with further flexibilities as compared to developed countries. In addition to sensitive products, they are allowed to designate special products (SP), taking into account their vulnerabilities and concerns over food security, livelihood security and rural development. Also, they have a right to implement the special safeguard mechanism (SSM), in addition to a current special safeguard which is applicable to all members, based on a mechanical rule, triggered by import price and quantity. In the market access negotiations, the US pushed for further tariff reduction. While developing countries, especially importing developing countries, called for broader flexibilities regarding special products and SSM, developed countries and exporting developing countries were against them. Although agriculture accounts for only a small portion in global trade, it has been politically sensitive. Thus, it was clear from the beginning that 
agriculture would be the driving force for the negotiations.

The objective of domestic support negotiations is to substantially reduce trade-distorting domestic support for agricultural products. Members who have a higher level of agricultural subsidies will face more reductions. Among several categories of trade distorting subsidies, overall trade distorting subsidies (OTDS) is at the heart of the talks. As the US is the biggest subsidizer, the EU, Brazil, and India demanded that the US cap its subsidies. While the US agreed to put limits on its subsidies, there were huge disparities between the amounts that the US suggested and that the others demanded.

Export competition negotiations aims to abolish export subsidies and to strengthen rules on exports credits and food aid. Members agreed to eliminate all forms of export subsidies by the end of 2013 at the Hong Kong Conference in $2005,{ }^{27}$ which was one of the modest achievements of the Ministerial Conference. Although no member denies the essential value of food aid for humanitarian purposes, subsidized export credits, including various forms of food aid, were seen as disguised export subsidies that circumvent rules regulating export subsidies. The US pushed for the introduction of strengthened discipline in these areas. By contrast, the EU and developing countries called for improved enforcement of existing rules.

The NAMA negotiations aim to increase market access on all non-agricultural products, including manufactured, fishery and forestry products. The objective is to eliminate tariff peaks ${ }^{28}$ of developed countries and to reduce high tariffs of developing countries. Developing countries, small and vulnerable economies (SVE) and least-developed countries (LDC) would have flexibilities. In addition to the tariff reduction formula, sectoral liberalization has been discussed. The aim of sectoral negotiations is to eliminate tariffs on specific sectors on the basis of non-mandatory participation. Once participating countries with a certain trade volume form a critical mass in a sector, they should liberalize trade in such sector on a most-favored-nation basis, which means they should provide free market access to products from non-participating countries as well as from participating countries. In addition, non-tariff barriers have also been an integral part of the negotiations. It is expected that sectoral liberalization and removal of non-tariff barriers will lead to significant market access. However, the positions taken by the G4 on tariff reduction are polarized. The US and EU claimed developing countries should also reduce tariffs substantially, although not as much as developed countries. On the other hand, Brazil and India argued the US and EU's request for developing countries' tariff reduction was excessive. With regard to sectoral liberalization, developed countries (and in particular the US) were active proponents and urged other members to participate, as they perceived the formula-based approach would not generate sufficient market access. In contrast, developing countries, including emerging economies such as China and India, maintained 
somewhat lukewarm positions and emphasized that participation in the sectoral liberalization should be voluntary in principle.

The rules negotiations aim to clarify and improve current disciplines of antidumping and subsidies, including fisheries subsidies. ${ }^{29}$ It is essential to have clear and effective rules and disciplines to prevent any abuse of trade remedy measures, as improved market access that results from negotiations can be undermined by abuse of trade remedy measures intended to protect domestic industries. Among the three areas of rules negotiations, anti-dumping is most intensively discussed. The Friends of Anti-dumping Negotiations (FANs) ${ }^{30}$ aggressively called for improved rules to prevent abuse of anti-dumping measures. In contrast, the US emphasized the usefulness of the measures and the necessity to maintain them, and EU shared the US' position in general. Developing countries stressed that it was important to keep costs and burdens on administration to minimum level.

The objective of fisheries subsidies negotiations is to improve disciplines of fisheries subsidies in particular. Fisheries subsidies are important in terms of environmental reasons as well as trade policy. The Friends of Fish group ${ }^{31}$ claimed fishery subsidies should be prohibited extensively, as imminent depletion of fishery stocks are the result of over-fishing and the fishing overcapacity caused by various subsidies programs. Other members, such as Korea, Japan, Chinese Taipei, as well as the EU argued that not all fisheries subsidies cause over-fishing and overcapacity, and thus, the scope of prohibition should be restrained to subsidies that actually have an adverse effect on fishery resources.

Market access to agricultural products, domestic support of agriculture, and NAMA have been considered the three pillars of the DDA negotiations. For the successful completion of the DDA, it is imperative for key parties to make concessions from their different positions in these areas. However, the positions of influential countries regarding the three pillars have been interlocked. The US and EU have pressed Brazil and India to reduce their tariff on agricultural and manufactured products substantially. Brazil and India have requested that the US cut its agricultural subsidies considerably, and that the EU reduce its tariffs on agricultural products drastically. Likewise, the US called for the EU to provide further access to its agricultural market, and the EU demanded that the US remove substantial amounts of its agricultural subsidies. In order to untangle various situations, at least one member has to make concessions so that the negotiations can move forward. However, no member is willing to initiate a meaningful first move unless they are confident that their concession will be followed by other members' concessions.

In addition, there have been other issues. Although these concerns may be considered as minor in a sense that they are not pillars of the negotiations, they are also essential elements of the negotiations which can unexpectedly turn into a deal breaker. These issues include: tariff capping, cotton subsidies, the scope of sensitive 
products and SPs, triggers for SSMs in negotiations on agriculture, sectoral liberalization in NAMA negotiations, and zeroing and fisheries subsidies in rules negotiations. In fact, what led to the collapse of the talks in 2008 were triggers for SSMs. Although the chairs of agriculture and NAMA negotiating groups tabled revised drafts which nearly reached consensus, and members managed to resolve 18 out of 20 issues set before them by Director-General Lamy, members failed to settle their differences on the price and quantity of imported agricultural products that allow developing countries to apply SSMs to cope with surges in imports.

By the end of 2010, there was sense of urgency shared by members who viewed 2011 as the window of opportunity to complete the DDA. DirectorGeneral Lamy urged members to intensify negotiations so that they could meet a schedule to circulate revised texts in April, agree on modalities by July, and submit and verify members' schedules of concessions by the end of December 2011 . However, as the US and emerging economies failed to diminish the difference between their positions on sectoral liberalization, he was unable to circulate revised text in April as planned. The DDA has been in stalemate since then.

\section{DIAGNOSIS: WHAT ARE THE PROBLEMS?}

\section{Structure: Negotiating Mechanism}

The DDA is the ninth multilateral trade negotiations in the history of the GATT and the WTO, and the first negotiations after the establishment of the WTO. It differs from previous rounds in several aspects. First, the number of participants in negotiations has increased over time. As Table 1 presents there were only 23 participants at the first Geneva Round in 1947 and that number increased to more than 125 participants at the UR negotiations. Furthermore, as of May 2013, the WTO consists of 159 members, all of which are participating in the DDA.

TABle 1. Outcomes of Multilateral Trade Negotiations of GATT

\begin{tabular}{cccccc}
\hline Round & Years & $\begin{array}{c}\text { Numbers of } \\
\text { Countries }\end{array}$ & $\begin{array}{c}\text { Value of Trade } \\
\text { covered }\end{array}$ & $\begin{array}{c}\text { Average } \\
\text { Tariff cut }\end{array}$ & $\begin{array}{c}\text { Average tariff } \\
\text { afterwards }\end{array}$ \\
\hline Geneva & 1947 & 23 & $\$ 10$ billion & $35 \%$ & N/A \\
\hline Annecy & 1949 & 33 & N/A & $35 \%$ & N/A \\
\hline Torquay & 1950 & 34 & N/A & $35 \%$ & N/A \\
\hline Geneva & 1956 & 22 & $\$ 2.5$ billion & $35 \%$ & N/A \\
\hline Dillon & $1960-1961$ & 45 & $\$ 4.9$ billion & $35 \%$ & N/A \\
\hline Kennedy & $1962-1967$ & 48 & $\$ 40$ billion & $35 \%$ & $8.7 \%$ \\
\hline Tokyo & $1973-1979$ & 99 & $\$ 155$ billion & $34 \%$ & $6.3 \%$ \\
\hline Uruguay & $1986-1994$ & 125 & $\$ 3.7$ trillion & $38 \%$ & $3.9 \%$ \\
\hline Doha & $2001-$ & $159+$ & & & \\
\hline
\end{tabular}

SOURCE: John Jackson, The World Trade System. 
It is not only the number of participants that has changed. The configuration of membership has also changed over time. Of the original 23 contracting parties of the GATT in 1947, 12 were developed countries. By the end of 1950, developed countries were still a majority with 21 among the GATT's 37 contracting parties. A sharp change in numeral balance occurred in the 1960s when a large number of British and French colonies achieved independence. In May 1970, the GATT consisted of 77 contracting parties with 25 developed and 52 developing countries. By 1987, the number of contracting parties rose from 77 to 97; all the new conracting parties were developing countries. Although developing countries were a majority at the UR negotiations, developed countries, in particular, the US and EU, continued to exert their leadership. For example, in November 1992, the US and EU reached an agreement over agricultural subsidies. As the bilateral talks were held at the Blair House in Washington D.C., the agreement between the US and EU was called the 'Blair House Agreement.' Although it was merely an agreement between two of more than 100 participants, it achieved a significant breakthrough in the negotiations. However, even with a breakthrough made by the Blair House Agreement, the talks were interrupted because of participants' discord over cuts in tariffs on manufactured products. And it was the agreement made by the Quad (the US, EU, Canada, and Japan) on market access of manufactured products that revitalized the negotiations. These examples show how less than a handful of countries played leading roles in the UR negotiations. In addition, between late November and mid December 1993, the US and EC engaged in intensive bilateral talks at a senior officer level with a goal to reach agreements no later than December $15 .^{33}$ The target date of December 15 was set because of the US' fast track negotiating authority. ${ }^{34}$ The authority had been initially set to expire on May 31, 1993 but was extended to April 15, 1994 to accommodate the UR negotiations. As the President of the US was required to transmit trade agreements to Congress no later than 120 days prior to the expiration of the authority, December 15 was set as a target date to conclude the UR negotiations to meet the procedural requirement of the US. The time frame of one country, since it was of the US, was a decisive element in wrapping up a multilateral trade negotiation in which 117 countries participated. ${ }^{35}$ On the whole, a few developed countries determined the outcomes of the UR negotiations, although the outcomes were accepted by all participants at the end of the day. The agreement between the US and EU was not only a required condition but almost a sufficient condition for the success of the whole negotiations.

However, developed countries are no longer main decision makers in the DDA as in previous rounds. While the US, the EU, Canada and Japan were referred to as Quad in the GATT parlance, in the DDA parlance, the G4 or New Quad refers to the US, EU, Brazil and India. G7 refers to the US, EU, Brazil, India, Japan, Australia and China. ${ }^{36}$ Agreements between these members were essential to make progress in the DDA talks, and thus, agreements between a few developed 
countries were no longer a sufficient condition for the completion of negotiations. On occasion, invitations to small group meetings are extended to Canada, Malaysia, Egypt and Kenya. Moreover, it is not only large emerging economies that have fair seats in negotiations. Small, less developed countries with common interests have formed groups to have their voices heard. For example, Antigua and Barbuda, Barbados, Belize, Benin, Côte d'Ivoire, Saint Kitts and Nevis, Saint Lucia, Saint Vincent, Trinidad and Tobago, etc. made a group called the G33 and pressed for broad flexibility in special products and SSM for developing countries. Therefore, various voices reflecting diverse interests emerged, unlike in previous rounds. In the DDA talks, developing countries were no longer passive members. They actively participated in the negotiations, which resulted in conflicts of interests on various issues. There is no doubt that economic rise of major developing countries will work for the benefit of multilateral trading system in the long run. However, the change in political and economic landscape has made the course of the DDA negotiations more difficult.

Despite the difference between previous negotiations rounds and the DDA, members decided to adopt a single undertaking rule that was used in the UR to use in DDA talks. Under the single undertaking rule, "nothing is agreed until everything is agreed." This means negotiations are complete when agreements are achieved in all areas, which covers agriculture, NAMA, service, rules, intellectual property rights, and more. The rule was initially introduced to facilitate negotiations by encouraging participants to compromise in one field knowing that they could receive something in exchange in another field. When there are a limited number of participants involved, the rule may promote concessions among them. However, this was not the case in Doha. The single undertaking has hindered progress in the negotiations. Pending progress in one field would freeze negotiations in other fiends, rather than being positively affected by development made in other areas. ${ }^{37}$ With an increased number of participants and interests, bargaining became more complicated. Negotiations became like a chess game with multiple players. Also, participants would not make concessions because of concern about other countries freeloading. Even when more participants were ready to make concessions, if a few participants refused to make equivalent concessions, the negotiations would stall, which means a few members could essentially block negotiations. Also, if participants did not make meaningful concessions, the talks would end up with lowest common denominator outcomes. While the single undertaking rule may be an efficient method of negotiations when there is limited number of decision makers, as in the UR negotiations, it was not effective in the Doha talks where members' diverse interests on various issues became entangled. Even when members reached agreement on 18 out of 20 issues on the table, disagreement over one issue could make the already-achieved 90 points score meaningless by bringing it down to zero, which happened in July 2008 at Geneva. 
As a whole, members failed to equip DDA with a proper negotiating mechanism in accordance to the altered geopolitical background against which the negotiations have been played out.

\section{Substance: Positions at Odds}

Members' tariffs have been reduced gradually through previous rounds as Table 1 shows, and, as a result of the UR, they were reduced further as shown in Table 2. Developed countries' average tariffs on manufactured products fell to $3.3 \%$. Developing countries' tariffs were also reduced but they still remained much higher than those in developed countries.

TABLE 2. OUTCOMES OF THE UR NegOTIATIONS

\begin{tabular}{cccc}
\hline \multirow{2}{*}{ Members } & \multicolumn{2}{c}{ Average Tariff Cut } & $\begin{array}{c}\text { Service Market } \\
\text { Access Rates }\end{array}$ \\
\cline { 2 - 3 } & Agricultural Products & Manufactured Products & $50 \%$ \\
\hline Korea & $26.7 \%$ & $54.6 \%$ & $69 \%$ \\
\hline US & $38 \%$ & $33 \%$ & $71 \%$ \\
\hline EU & $37 \%$ & $34.5 \%$ & $61 \%$ \\
\hline Japan & $36 \%$ & $56 \%$ & $60 \%$ \\
\hline Canada & $37 \%$ & $44.9 \%$ & $57 \%$ \\
\hline Australia & $45 \%$ & $39 \%$ & $46 \%$ \\
\hline Philippines & $45 \%$ & $50 \%$ & $26 \%$ \\
\hline Indonesia & $30 \%$ & $5 \%$ & $31 \%$ \\
\hline Thailand & $33 \%$ & $51 \%$ & $35 \%$ \\
\hline
\end{tabular}

SOURCE: Ministry of Foreign Affairs, Korea, Results of the UR Negotiations.

At the DDA, the US and EU aimed to substantially reduce emerging economies' tariffs, in particular, of China, Brazil, and India, on manufactured products. Also, they urged these emerging economies to participate in sectoral liberalization. They insisted that China, Brazil and India had to take responsibility commensurate with their shares in global trade and their positions in the global economy. However, as developed countries' tariffs were already low, they did not have much to offer in exchange for the deep tariff cuts and further liberalization they requested, other than capping the US' agricultural subsidies and reducing the EU's tariffs on agricultural products.

China, Brazil and India opposed the US and EU's requests for deep cut on their tariffs. China claimed they had already opened up their market to the level equivalent to those of developed countries as a result of their WTO accession negotiations and thus that they should not be asked for further liberalization. ${ }^{38}$ Brazil and India emphasized that the DDA was a negotiations round to address 
developmental concerns. The US and EU sought outcomes in balance between them and emerging economies, as they were of the opinion that the Ministerial Declaration constituted a carefully constructed balance of interests between economies at all stages of development. In contrast, China, Brazil and India insisted that the DDA was not intended to achieve such result, as it should be devoted to developing countries' concerns. Although the US and EU understood that the goals of negotiations were not only trade liberalization but also to address needs and interests of developing countries, it seems the US, EU and Brazil, China, India did not share the same definition of 'developing' countries. While Brazil, China and India did not have any doubt that they were developing countries, the US and EU did not consider these to be emerging economies, especially China, which is literally a global manufacturing engine, to be an ordinary developing country, at least in the DDA context. Developing countries are supposed to bear fewer burdens than developed countries in various areas of the negotiations. They would be subject to less tariff reductions with more flexibilities such as designation of SPs and recourse to SSMs with regard to agricultural products. In terms of the WTO rules, they would be subject to special and differential treatments (SDT) for developing countries. Although China's GDP has already exceeded that of Japan and will overtake that of the US in a few years, as a developing country China can still claim these benefits. Here exists an irreconcilable difference in the positions taken by developed countries and emerging economies.

In fact, while less than half of global GDP growth came from developing countries between 1998 and 2001, it is expected to reach more than $75 \%$ between 2011 and 2014. ${ }^{39}$ The rapid growth of emerging economies is at the center of this expansion. Likewise, the US, EU and other developed countries' concerns about emerging economies' high tariffs on manufactured products have grown since the launch of the DDA, and they are much less patient about emerging economies now than they were in 2001. Therefore, it is quite understandable that the deal breaker in April 2011 was sectoral liberalization.

In addition, the financial crisis of 2007 and 2008, which was followed by a downturn in economic activity leading to the global recession of 2008-2012, also had a negative impact on the DDA. During an economic recession, governments are tempted to turn to protectionist measures such as export subsidies, high tariffs and anti-dumping measures to prop up their economies. Thus, advancing negotiations for further trade liberalization is unlikely to be among their top priorities.

As a whole, key players had completely different expectations for the outcomes of the negotiations from the outset. The differences in their positions based on such expectation became broader over time. Due to the significant disparities in major parties' expectations and entrenched positions, the DDA was set on a foundation where agreements were unforeseeable. 


\section{CONCLUSION}

The DDA negotiations were launched in 2001 with a goal of further trade liberalization and improvement of existing WTO rules. However, two years have passed since it deadlocked in April 2011. This paper has examined what has caused the current impasse of the DDA. In order to address this question, the paper has reviewed the history of the DDA and analyzed critical issues of the negotiations. The DDA covers negotiations over nine areas, among which negotiations on agriculture, NAMA and rules have been at the center. Although members have made progress in the negotiations, they were unable to reach a consensus, even after a decade of negotiations. It was largely because key players failed to reduce gaps in their positions on critical issues, such as market access of agricultural products, domestic supports for agriculture, and NAMA.

On the basis of its analysis, this paper finds that there are two elements that led to the current situation. First, the negotiating mechanism of the DDA was inefficient. Unlike in previous rounds, the US and EU were unable to exert their leadership and act as decision makers in the DDA. Instead, developing countries actively engaged in the negotiations and a few of them, namely Brazil, India, and China, became major parties. With developing countries' increased participation, diverse and conflicting interests of members surfaced. Members, however, adopted a single undertaking rule as their negotiating method as they did in the UR. While the single undertaking rule worked relatively well before, it turned out to be highly inefficient within the new negotiating environment. Second, developed countries and emerging economies had vastly different expectations for the outcomes of the negotiations from the beginning, and their positions based on these expectations have not converged through negotiations. Developed countries pointed out the current stance and share of emerging economies in global trade, and requested from them a substantial removal of trade barriers. In contrast, emerging economies emphasized that the DDA was a development round, unlike previous rounds, designed to address the concerns and needs of developing countries. They claimed that developed countries' requests did not meet the intention of the DDA. As a whole, the DDA was not equipped with a negotiating mechanism to cope with the new negotiating environments, and critical parties did not share a common vision of the negotiations from the onset, and thus, their positions remained at odds.

The future of the DDA is uncertain. On the one hand, there are arguments that the DDA has failed, and it is time to abandon Doha and move forward. ${ }^{40}$ As prolonging the DDA would jeopardize the multilateral trading system, it is argued that members should salvage partial agreements and then, close the DDA, which is called Plan B. ${ }^{41}$ In the same vein, WTO members should concentrate on focused projects, like the WTO's plurilateral Government Procurement Agreement (GPA) and the Information Technology Agreement (ITA), and conduct small sectorspecific negotiations from this point forward. ${ }^{42}$ On the other hand, it is claimed 
the Doha negotiation is not dead, although it is clearly at a critical stage, and members should continue trying to resolve remaining disagreements. ${ }^{43}$ The reason is, firstly, the huge investment in terms of the time and effort made in completing Doha, and abandoning Doha means abandoning all the investment in political credibility. Secondly, it would be no less difficult to decide what should be included under Plan B than to pursue completing the entire Doha deal. ${ }^{44}$ This observation turned out to be correct, as it was witnessed that key players rejected a proposal to agree on a small agreement planned for December at meetings held in June and July, 2011. ${ }^{45}$ Even if we gave up the DDA now and tried to start another negotiation round in the future, the agenda would still include such issues as market access to agricultural and non-agricultural products and domestic support of agriculture. And these issues would similarly turn out to be the stumbling block. ${ }^{46}$ Thirdly, should the DDA fail, trade liberalization would shift from a multilateral trading system, represented by the WTO, to regional trade agreements (RTAs), which are already springing up. It is argued that RTAs are "termites in the trading system" that foster harmful trade diversion by increasing discrimination against non-members. ${ }^{47}$

There might be disagreement over whether RTAs are indeed termites in the trading system, as RTAs also have their merits. However, it would be less disputable that a multilateral trading system, based on non-discrimination principle, should be the backbone of the international trade system and RTAs should take supplementary roles rather than being an alternative. In fact, members are becoming more inclined to form RTAs because of the lack of progress made at Doha. It is possible to achieve a higher level of trade liberalization through RTAs in terms of market access, as the basic element of free trade agreements (FTAs) is elimination of tariffs for free movement of goods among parties. However, when it comes to introducing rules and disciplines, RTAs have limitations. Common rules for all members can only be introduced through multilateral trade negotiations, which provide more predictability and security to global markets. And thus, the conclusion of the DDA would strengthen the WTO's role in creating policy stability and in reducing the probability that WTO members will resort to protectionism. ${ }^{48}$ It is for this reason that members should make a last ditch effort and preserve to complete the DDA. ${ }^{49}$ In addition, although key players' disagreements on critical issues have brought the DDA into deadlock, as Director General Lamy correctly stated, nearly $80 \%$ of the deal is complete. Thus, major parties must make marginal concessions to finalize the agreement, although the outcome may fall short of the ambitious goals that were conceived in 2001.

\section{REFERENCES}

Bhagwati, Jagdish. 2011, April 28. The Doha Round's Premature Obituary. Project Syndicate. 
Bhagwati, Jagdish. 2011, May 17. Dead Parrot Trade Talks. Project Syndicate.

Bhagwati, Jagdish. 2011, May 30. Life without Doha. Project Syndicate.

Baldwin, Richard., and Simon Evenett. 2011. Keeping the WTO on Track: A Doha

Down Payment Plus More in Richard Baldwin and Simon Evenett (ed.), Next

Steps: Getting Past the Doha Round Crisis 61-70. VoxEU.org eBook, Centre for Economic Policy Research.

Bhatia, Ujal Singh. 2011. Next Steps: Getting Past the Doha Round Crisis in Richard Baldwin and Simon Evenett (ed.), Next Steps: Getting Past the Doha Round Crisis 33-40. VoxEU.org eBook, Centre for Economic Policy Research.

Economist. 2008, July 17. Defrosting Doha.

Economist. 2008, July 31. So Near and Yet So Far.

Economist. 2011, April 28. Deadman Talking.

Economist. 2012, September 9. Goodbye, Doha, Hello, Bali.

Financial Times. 2008, July 29. What's at Stake in Doha Talks.

Financial Times. 2009, July 29. India Damps Hopes of New Doha Talks.

Financial Times. 2009, October 2. End in Sight for Doha Talks, Says Crean.

Financial Times. 2011, April 18. Life after Doha.

Financial Times. 2011, May 1. WTO Keeps Faith with Stalling Doha Talks.

Financial Times. 2011, June 23. Hopes Fade for Accord at Doha Talks.

Financial Times. 2011, July 26. Doha Trade Round Suffers Fresh Blow.

Harbinson, Stuart. 2009. The Doha Round: 'Death-Defying Agenda' or 'Don't Do it Again?' ECIPE Working Paper, No.10.

Harbinson, Stuart. 2011. The Good Ship Doha: Salvage-and-Abandon-Ship or Repair-and-Wait? in Richard Baldwin and Simon Evenett (ed.), Next Steps: Getting Past the Doha Round Crisis 51-60. VoxEU.org eBook, Centre for Economic Policy Research.

Hoda, Anwarul. 2001. Tariff Negotiations and Renegotiations under the GATT and the WTO-Procedures and Practices. Cambridge University Press.

Hoekman, Bernard. 2010. Will Martin and Aaditya Mattoo, Conclude Doha: It Matters! World Trade Review 9(3): 505-530.

Hufbauer, Gary, and Dean DeRosa. 2011, May. Trade Policy after Doha, G20 in the Global Economy. German Marshall Fund of the United States.

Jawara, Fatoumata, and Aileen Kwa. 2003. Behind the Scenes at the WTO: the Real World of International Trade Negotiations. Zed Books.

Lal Das, Bhagirath. 2007. The Current Negotiations in the WTO-Options, Opportunities and Risks for Developing Countries, 2nd ed., Third World Network.

Pangestu, Mari. 2011. There is no Plan B-only Plan A: Towards Completing Doha in Richard Baldwin and Simon Evenett (ed.), Next Steps: Getting Past the Doha Round Crisis 19-26. VoxEU.org eBook, Centre for Economic Policy Research.

Polaski, Sandra. 2006. The Future of the WTO, Policy Outlook. Carnegie Endow- 
ment for International Peace.

Schott, Jeffrey J. 2006, October. Completing the Doha Round, Policy Brief, Number PB06-7. Peterson Institute for International Economics.

Schott, Jeffrey J. 2011, June. What Should the United States Do about Doha?, Policy Brief, Number PB11-8. Peterson Institute for International Economics.

Schwab, Susan C. 2011, May/June. After Doha: Why the Negotiations Are Doomed and What We Should Do About It. Foreign Affairs 90(3): 104-117.

Schwab, Susan C. 2011. Acknowledge Doha's Demise and Move on to Save the WTO in Richard Baldwin and Simon Evenett (ed.), Next Steps: Getting Past the Doha Round Crisis 27-32. VoxEU.org eBook, Centre for Economic Policy Research.

Sun, Zhenyu. 2011. Next Steps: Is an Early Harvest Still Possible? in Richard Baldwin and Simon Evenett (ed.), Next Steps: Getting Past the Doha Round Crisis 41-46. VoxEU.org eBook, Centre for Economic Policy Research.

Weekes, John. 2011. Getting Past the Doha Round Crisis: Moving forward in the WTO in Richard Baldwin and Simon Evenett (ed.), Next Steps: Getting Past the Doha Round Crisis 47-50. VoxEU.org eBook, Centre for Economic Policy Research.

WTO. 2001. Ministerial Declaration. WT/MIN(01)/DEC/1. November 20, 2001.

WTO. 2003. Ministerial Statement. WT/MIN(03)/20. September 23, 2003.

WTO. 2004. Doha Work Programme-Decision Adopted by the General Council on 1 August 2004. WT/L/579. August 2, 2004.

WTO. 2005. Doha Work Programme-Ministerial Declaration. WT/MIN(05)/DEC. December 22, 2005.

WTO. 2007. Revised Draft Modalities for Agriculture. TN/AG/W/R. August 1, 2007.

WTO. 2007. Chairman's Introduction to the Draft NAMA Modalities. JOB(07)/ 126. July 17, 2007.

WTO. 2007. Draft Consolidated Chair Texts of the AD and SCM Agreements. TN/RL/W/213. November 30, 2007. 


\section{ENDNOTES}

1 Cover Note by TNC Chair, TN/C/13, April 21, 2011.

2 Susan Schwab, former USTR, claimed the international community should recognize the failure of DDA. See Susan C. Schwab, After Doha, Why the Negotiations are Doomed and What We Should Do about it, Foreign Affairs 90(3): 104-117. [Hereinafter, Susan Schwab, After Doha]

3 Ministerial Declaration, WT/MIN(01)/DEC/1, November 20, 2001. [Hereinafter, Doha Mi-nisterial Declaration]

4 Summits and trade ministers' meetings held in various occasions emphasized "ambitious and balanced outcome" should be achieved in DDA negotiations. See 11th Meeting of APEC Ministers Responsible for Trade, Ministerial Statement on DDA Negotiations, June 2005 (Jeju, Korea); 12th Meeting of APEC Ministers Responsible for Trade, Ministerial Statement on DDA Negotiations, June 2006 (Ho Chi Minh City, Viet Nam); 13th Meeting of APEC Ministers Responsible for Trade, Ministerial Statement on DDA Negotiations, July 2007 (Cairns, Australia); 13th APEC Economic Leaders' Meeting Statement on DDA, November 2005 (Busan, Korea); 14th APEC Economic Leaders' Meeting Statement on DDA, November 2006 (Hanoi, Viet Nam); 15th APEC Economic Leaders' Meeting Statement on DDA, September 2007 (Sydney, Australia).

5 Doha Ministerial Declaration, supra note 3.

6 Ministerial Statement, WT/MIN(03)/20, September 23, 2003.

7 At the Second Ministerial Conference in Singapore, WTO members agreed to establish working groups to examine relations between trade and investment, trade and competition policy, and to conduct a study on transparency in government procurement practices, and on the simplification of trade procedures. These issues were referred to as 'Singapore issues.'

8 G10 consists of Korea, Japan, Chinese Taipei, Norway, Switzerland, etc. and represents countries that mainly import agricultural products.

9 G20 consists of Argentina, Brazil, China, Chile, India, Mexico, Indonesia, etc. and presents developing countries that have advantage on agricultural industries. G20 call for elimination of domestic subsidies and export support provided by developed countries.

${ }^{10} \mathrm{G} 33$ consists of Antigua and Barbuda, Barbados, Belize, Botswana, Jamaica, Honduras, India, Indonesia, Korea, etc. that call for broad flexibilities to developing countries.

11 WTO, Doha Work Program, WT/L/569, August 22004.

12 WTO, Doha Work Program-Ministerial Declaration, WT/MIN(05)/DEC, December 22, 2005. [Hereinafter, Hong Kong Ministerial Declaration].

${ }^{13}$ Id.

14 Id.

${ }^{15}$ Revised Draft Modalities for Agriculture, TN/AG/W/4, August 1, 2007; Chairman's Introduction to the Draft NAMA Modalities, JOB(07)/126, July 17, 2007.

${ }_{17}^{16}$ Doha Declaration, supra note 3, paras. 13, 14 .

${ }^{17} I d$, para. 16.

${ }_{18} I d$, para. 15.

${ }^{19} I d$, paras. 28, 29.

${ }^{20} \mathrm{Id}$, paras. 17-19.

${ }^{21} I d$, paras. 31-33.

${ }^{22} I d$, para. 30.

${ }^{23} I d$, para. 27.

${ }^{24}$ While the other eight areas were included in negotiating agenda in Doha Ministerial Declaration in 2001, trade facilitation was later added to the agenda by the Framework Agreement in 2004.

${ }^{25}$ Doha Ministerial Declaration, supra note 3, para. 12.

${ }^{26} I d$, para. 44.

${ }^{27}$ Hong Kong Ministerial Declaration, supra note 12, para.6.

${ }^{28}$ Developed countries had reduced their tariff on manufactured products over time and thus, their overall tariffs are already quite low. However, there are several items with high tariffs, which are referred to as 'tariff peak.'

${ }^{29}$ The negotiations also cover RTA. However, the paper will limit its scope of analysis to antidumping and subsidies as there have not been much discussion on RTA as compared to other areas. 
${ }^{30}$ The FANs, consisting of Korea, Japan, Brazil, Mexico, Chile, Hong Kong, Chinese Taipei, etc., press for stronger regulations on anti-dumping measures.

31 The Friends of Fish group consists of the US, Australia, New Zealand, Chile, Argentina, etc.

32 The average tariffs, in Table 1, refer to tariffs on non-primary products of developed countries.

${ }^{33}$ The US and EU held senior office meetings (SOM) on November 22-23, December 1-2, and 6 7.

${ }^{34}$ US Trade Act of 1974, §151-154 (19 U.S.C. \$2191-2194). Although the US Constitution enables only Congress to get into trade negotiations with other countries, when Congress grant the fast track negotiating authority to the President, the execute branch can engage in negotiations. Also, Congress should employ procedural rules that move implementing bill faster through the process, without normal debate and cloture rule. In addition, Congress cannot amend the legislation. It can either reject or pass it without amendment.

35117 countries participated in the UR negotiations as of December 15, 1993 and 8 more countries later joined the GATT in accordance to Article 26 of GATT 1947.

${ }^{36}$ The G7 in DDA parlance is different from conventional meaning of the term. Conventionally, the G7 refers to the US, UK, France, Germany Italy, Canada and Japan.

37 Stuart Harbinson, The Doha Round, 'Death-Defying Agenda' or 'Don't Do it Again?' ECIPE Working Paper, 2009.

${ }^{38}$ Protocol on the Accession of the People's Republic of China, WT/L/432 (2001).

39 Economist, Dead Man Talking, April 28, 2011.

${ }^{40}$ Susan Schwab, After Doha, supra note 2.

${ }^{41} \mathrm{Id}$.

${ }^{42}$ More generally, see Life After Doha, Financial Times, April 11, 2011; Dead Man Talking, Economist, April 28, 2011; and, Goodbye Doha, Hello Bali, Economist, September 8, 2012.

${ }^{43}$ More generally, see Jagdish Bhagwati, Life without Doha, Project Syndicate, May 30, 2011; Mari Pangestu, There is no Plan B-only Plan A: Towards completing Doha in Richard Baldwin and Simon Evenett (eds.), Next Steps: Getting Past the Doha Round Crisis, Centre for Economic Policy Research, 2011; Ujal Singh Bhatia, Next Steps: Getting Past the Doha Round Crisis Doha in Richard Baldwin and Simon Evenett (eds.), Next Steps: Getting Past the Doha Round Crisis, Centre for Economic Policy Research.

${ }^{44}$ Stuart Harbinson, The Doha Round: 'Death-Defying Agenda' or 'Don't Do it Again?' ECIPE Working Paper, No.10/2009.

${ }^{45}$ More generally, see Hopes Fade for Accord at Doha Talks, Financial Times, June 23, 2011; and, Doha Trade Round Suffers Fresh Blow, July 26, 2011.

46 Stuart Harbinson, The Doha Round, supra note 45.

${ }^{47}$ See Jagdish Bhagwati, The Doha Round's Premature Obituary, Project Syndicate, April 11, 2011; and Jagdish Bhagwati, Dead Parrot Trade Talks, Project Syndicate, May 17, 2011.

48 Bernanrd Hoekman, Will Martin and Aaditya Mattoo, Conclude Doha: it matters!, World Trade Review 9(3): 505-530.

49 Also, see Stuart Harbinson, The Good Ship Doha: Salvage-and-Abandon-Ship or Repair-and-Wait? in Richard Baldwin and Simon Evenett (eds.), Next Steps: Getting Past the Doha Round Crisis, Centre for Economic Policy Research. 